\section{Studia}

\section{z Filologii Polskiej i Słowiańskiej}

DOI: $10.11649 /$ sfps.1598
Studia z Filologii Polskiej i Słowiańskiej, 54

Warszawa 2019

Article No. 1598

Citation:

Parafińska-Korybska, E. (2019). Leksyka muzyczna w rosyjsko-polskiej leksykografii: Stan obecny versus potrzeby użytkowników. Studia z Filologii Polskiej i Słowiańskiej, 54. https://doi.org /10.11649/sfps.1598

\author{
Ewelina Parafińska-Korybska \\ (Katolicki Uniwersytet Lubelski Jana Pawła II)
}

\title{
Leksyka muzyczna w rosyjsko-polskiej leksykografii. Stan obecny versus potrzeby użytkowników
}

Słowniki dwujęzyczne są bez wątpienia pierwszym i najbardziej wiarygodnym źródłem, po które sięgamy, gdy pojawia się potrzeba przetłumaczenia jakiejś jednostki leksykalnej. Nie ma też wątpliwości, że recenzowany słownik, wydany w formie tradycyjnej, czyli papierowej, wzbudza większe zaufanie niż pomoce internetowe. $Z$ drugiej jednak strony bezkrytyczne korzystanie wyłącznie z jednego źródła rodzi niebezpieczeństwo powielania błędów niepoprawnie dobrany w słowniku translat bądź też błędne wskazanie jego użycia rozpowszechnia się wśród użytkowników, co oczywiście jest zjawiskiem niepożądanym.

Oferta źródeł leksykograficznych jest szeroka i obejmuje bardzo różne objętościowo pozycje. W niniejszym artykule analizie poddano materiał dwóch słowników, które opatrzone są tytułowym przymiotnikiem „wielkie”: Wielki słownik rosyjsko-polski A. Mirowicza i in., wyd. Wiedza Powszechna (zwany dalej słownikiem WP; Mirowicz, 1993), oraz Wielki słownik rosyjsko-polski z kluczem polsko-rosyjskim pod red. Jana Wawrzyńczyka, wyd. PWN

This is an Open Access article distributed under the terms of the Creative Commons Attribution 3.0 PL License (creativecommons.org/licenses/by/3.0/pl/), which permits redistribution, commercial and non-commercial, provided that the article is properly cited. (c) The Author(s) 2019.

Publisher: Institute of Slavic Studies, Polish Academy of Sciences

[Wydawca: Instytut Slawistyki Polskiej Akademii Nauk] 
(Wawrzyńczyk, 2004) ${ }^{1}$, zwany dalej słownikiem PWN. Oba liczą po około 70 tys. haseł, co czyni je najobszerniejszymi- a przy tym najpopularniejszymi słownikami dwujęzycznymi (w parze rosyjsko-polskiej) na rynku polskim. Przy czym, jak podkreśla Bogumił Gasek, słownik Wiedzy Powszechnej (z 1973 r.) od lat nie był aktualizowany, dlatego zarzuca się mu niejednokrotnie przestarzałe słownictwo (Gasek, 2014). Słownik PWN z 2004 r. zgodnie z założeniem autorów ma spełniać oczekiwania odbiorców wobec „nowego, prawdziwie nowoczesnego słownika rosyjsko-polskiego” (Sobol, 2004, s. 5, wstęp). Celem niniejszego artykułu nie jest jednak analiza porównawcza materiału leksykograficznego obu słowników, ale zbadanie, w jakim stopniu słownik dwujęzyczny realizuje potrzeby użytkowników w zakresie dostępności odpowiedników leksyki muzycznej oraz w jakim stopniu rosyjsko-polskie warianty słownikowe pokrywają się semantycznie. Dokonane też będzie porównanie budowy artykułu hasłowego zawierającego leksem muzyczny w obu słownikach.

Dla przejrzystości analizy interesującą nas leksykę można pogrupować według różnych kryteriów, najbardziej podstawowym jest kryterium znaczeniowe. $Z$ obu słowników wyekscerpowano następujące klasy semantyczne:

- nazwy instrumentów, ich części i charakterystyka, np. аккордеон, банджо, дульце, духовой, многострунный, мундштук, смычок, фагот, челеста, щиикковоц̆;

- typy głosu, np. альт, дискант, контральто, тенор, фальщет;

- formy muzyczne, utwory i ich części, np. ария, вариация, застольная песня, запев, канон, ноктюрн, прелюдия, соната, частушка;

- nazwy tańców, nр. вальс, гавот, мазурка, тарантелла, чарльстон;

- muzyczne style i kierunki, np. блюз, поп-музыка, рок-н-ролл, рэп;

- wykonawcy muzyki oraz osoby zajmujące się muzyką, np. apøucm, вольнщик, дудочник, капельмейстер, органист, пианист, скрипач, хорист, иимбалист;

- nazwy czynności związanych z muzyką, np. аккомпанировать, детонировать, напевать, ритмизировать, солировать, спеваться;

${ }^{1}$ Na rynku polskim mamy jeszcze Wielki słownik polsko-rosyjski, rosyjsko-polski S. Chwatowa i in. z 2008 r., ale ze względu na mniejszy zakres słownictwa nie będzie on uwzględniony $\mathrm{w}$ analizie. 
- ogólne pojęcia muzyczne, np. абсолютный слух, бемоль, звукоряд, квинтет, мелодика, одноголосие, реприза, синкопа, темперация, тональность, цезура;

- określenia dynamiki, tempa i sposobów wykonawczych, np. aллегpo, модерато, пициикато, флажолет, щипком;

- urządzenia służące do odsłuchiwania muzyki, np. вокмэн, грамофон, динамик, магнитофон, радио;

- pojęcia związane ze sztuką teatralną, np. авансцена, аншлаг, бис, капельдинер, пьеса, софить, труппа.

Z powyższego zestawienia wynika, że słowniki rejestrują różnorodną leksykę muzyczną, która obejmuje zarówno terminologię, jak i słownictwo potoczne czy ogólnomuzyczne.

Jeśli zaś weźmiemy pod uwagę aspekt morfologiczny terminologii muzycznej, to zauważamy charakterystyczną dla tej grupy tematycznej przewage rzeczowników i przysłówków, znaczniej mniej przymiotników i czasowników, co podkreśla także Anna P. Borowska (Borowska, 2004). Muzyka jest dziedziną sztuki, która wznosi się ponad granice państw, o czym świadczy fakt, iż terminologia muzyczna powstała w krajach o bogatszych tradycjach muzycznych była przejmowana przez języki innych krajów. Do różnych systemów językowych przenikały zatem słowa o statusie internacjonalizmu, które utrwaliły się w języku i w takiej formie w nim pozostały (Mela, 2008). Terminologia muzyczna to jednak nie tylko słowa odnoszące się bezpośrednio do świata muzyki, jej teorii czy historii. Muzyka podlega bowiem prawom fizyki czy akustyki, matematyka zaś służy jej do uporządkowania wartości rytmicznych. Naturalne jest więc, że nazewnictwo $z$ tych i innych dziedzin przenika do zasobów leksyki muzycznej i ją współtworzy (Borowska, 2004). Mariusz Mela podkreśla jednak, że nie jest możliwe oddzielenie terminologii stricte muzycznej od leksyki, przejętej z innych dziedzin, gdyż są one ze sobą bardzo ściśle związane. Utrudnia to znacznie proces klasyfikacji leksyki, będący wstępem do tworzenia materiału leksykograficznego (Mela, 2008).

Odrębną kwestią jest zatem dobór ekwiwalentów tłumaczeniowych oraz różnice w formułowaniu artykułów hasłowych, o czym będzie mowa w dalszej kolejności.

Oczywiste jest również, że leksyką muzyczną posługują się nie tylko specjaliści. Spora część tej grupy słownictwa należy do języka ogólnego, ponieważ muzyka otacza człowieka i jest nieodłączną częścią jego życia w społeczeństwie. 
Stąd też obecność tego typu leksyki w obu wspomnianych wyżej słownikach dwujęzycznych. Michał Kozdra wyróżnia trzy rodzaje kryteriów, w oparciu o które konstruowane są artykuły hasłowe w słownikach. Są to kryteria: lingwistyczne, społeczno-polityczne oraz pragmatyczne. Leksyka muzyczna plasuje się w drugiej grupie, zatem jej obecność w słownikach uzasadniana jest także uwzględnianiem słownictwa $\mathrm{z}$ różnych zakresów tematycznych i dziedzin (Kozdra, 2017).

Jeżeli natomiast skupimy się na samej terminologii muzycznej, to wówczas zauważymy, że zakres jej występowania w obu słownikach jest różny. W słowniku WP zauważono znacznie więcej słów należących do leksyki specjalistycznej, a więc wykraczającej poza granice języka ogólnego, niż w słowniku PWN, nр. домбра, каватина, клавир, модерато, обертон, реприза. Моżnа осzуwiście pytać o zasadność umieszczania ich w słowniku ogólnym. Na korzyść pierwszego słownika przemawia też obecność przy tego typu artykułach hasłowych kwalifikatora мyз. (музыєк), czego nie odnajdziemy w słowniku PWN. Tu kwalifikatory wskazują jedynie na informację gramatyczną, m.in. przypadek gramatyczny, rodzaj czy status słowa, oznaczając je jako 'przestarzałe', 'potoczne' itp. Tymczasem słownik WP poza ww. kwalifikatorami przewiduje szereg innych oznaczeń, klasyfikujących jednostki leksykalne do poszczególnych dziedzin, np. ekonomii, lingwistyki, fizyki czy muzyki, co ułatwia użytkownikowi pracę ze słownikiem. O ile słowa takie jak саксофон, танго, джаз, клавиатура, бac nie wymagają obecności kwalifikatora, o tyle pożądana wydaje się jego obecność w przypadku słów typu интерлюдии, колоратурь, скерио, унисона. Mogą one być bowiem niezrozumiałe dla osoby, która nie zajmuje się muzyką, a napotka na słowo niewywołujące żadnych konotacji nawet w tłumaczeniu na język polski. Niektóre hasła w słowniku PWN posiadają jednak objaśnienia, przyporządkowujące leksem do danej dziedziny, w obrębie samego hasła, nр. интервал - 1. odstę, 2. (перерыв) przerwa, 3. (в акустике, музыке) interwat; перебор - 1. przebieranie, 2. (чередующиеся звуки струн, гармоники, колокольчиков и m.d.) pasaż, 3. (излищек) nadmiar / nadwyżka. Mamy więc tu do czynienia ze słowami, które używane są $\mathrm{w}$ dziedzinach pozamuzycznych, posiadającymi więcej niż jedno znaczenie. Słownik ów nie przewiduje jednak takich objaśnień dla wszystkich słów wieloznacznych, co może wprowadzić użytkownika w błąd lub co najmniej konsternację. Za przykład niech posłuży słowo uезура, które w obu słownikach przetłumaczono jako cezura. Słownik WP jednak opatruje słowo to kwalifikatorami lit. muz.cezura (literatura, muzyka), $\mathrm{w}$ artykule hasłowym słownika PWN widzimy zaś jedynie cezura (w wierszu), 
co wiąże się z pozbawieniem tego słowa jednego ze znaczeń. Podobnie rzecz ma się w przypadku słowa вариация - słownik WP - 1. wariacja, 2. муз. wariacje; słownik PWN - wariacja. Należy jednak dodać, że powyższe refleksje nie służą wartościowaniu jednego ze słowników, gdyż nie analiza porównawcza jest celem niniejszej pracy. Ponadto analizie poddano pewną grupę leksyki. Na jej podstawie nie można wysnuć obiektywnych wniosków na temat jakości całego materiału leksykograficznego obecnego w obu słownikach. Autor chciał jedynie zaakcentować pewne problemy, które mogą być wzięte pod uwagę w kolejnych opracowaniach leksykograficznych.

Bogumił Gasek wskazuje na brak kwalifikatorów w słowniku PWN, zbyt rozbudowane dyrektywy wyboru w obrębie artykułów hasłowych oraz niezbyt częste umieszczanie wskazówek dotyczących interpretacji, podczas gdy użycie kwalifikatora zwiększyłoby przejrzystość tekstu oraz zaoszczędziłoby miejsca w słowniku (Gasek, 2014). Przykładem niech będzie антракm - 1. (nерерыв между действиями спектакля или отделениями концерта, ииркового представления) рrzеrwa, 2. (музыкальное произведение) antrakt (słownik PWN). Sprawdźmy teraz, w jaki sposób artykuł hasłowy został opracowany w słowniku WP: 1. teatr. antrakt, przerwa, 2. muz. antrakt. Wydaje się, że jest to słowo już tak powszechne w użyciu, iż nie wymaga tak obszernej eksplikacji, jaka została zastosowana w słowniku PWN.

Jednakże nie w przypadku wszystkich słów wieloznacznych zawartych w obu słownikach można zaobserwować taką prawidłowość. Oba źródła podają bowiem poszczególne znaczenia słowa рондо. W słowniku WP odnajdziemy trzy oddzielne artykuły hasłowe: ро́ндо - муз. rondo; рондо́ - lit. rondo; рондо́ ${ }^{2}$ 1. (ирибт) rondo, 2. (nepo) rondówka. Zgodnie $\mathrm{z}$ informacją podaną we wskazówkach dla korzystających ze słownika umieszczenie cyfr arabskich po prawej stronie u góry wyrazów oznacza, iż są to homonimy. Słownik PWN również podaje oddzielne artykuły hasłowe dla poszczególnych znaczeń: ро́ндo - rondo (forma muzyczna); рондó - rondo (strofa). Oba słowniki nie podają natomiast rozróżnienia dla wyrazu болеро, tłumacząc je po prostu jako bolero, podczas gdy może ono oznaczać element garderoby oraz formę muzyczną (notabene, nie tylko takie objaśnienie w dziedzinie muzyki wyczerpałoby pojemność semantyczną tegoż słowa).

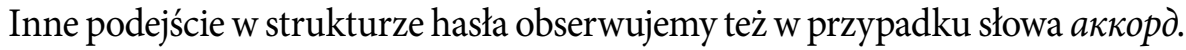
W słowniku Wiedzy Powszechnej: аккорд1 - muz. i przen. akord; aккорд2 - przest. układ, ugoda. Słownik PWN podaje jeden odpowiednik - akord. Rozróżnienie semantyczne można odnaleźć w dalszych hasłach: аккордныı̆ - akordowy (dotyczący pracy w akordzie); аккордныци - akordowy (dotyczący akordów muzycznych). 
W tym miejscu zwrócić należy uwagę na pewną cechę słownika PWN, jaką jest duża liczba form przymiotnikowych pochodnych od rzeczowników (nр. аккордеонныц - akordeonowy; блюзовыц - bluesowy; гобойныц - obojowy/ oboju; интервальныц - interwałowy) oraz takich przymiotników pochodnych od rzeczowników, które w tłumaczeniu na język polski są formami dopełniacza (nр. аккомпанементныц - akoтрапіатепtu; валторновый - waltorni; гобойныц - obojowy/oboји; инструменталистский - instrumentalisty). Tego typu artykuły hasłowe częściej spotkać można w słowniku PWN niż w słowniku WP. Gasek podkreśla rolę obecności ekwiwalentów słownikowych na poziomie części mowy, gdyż ułatwia to pracę ze słownikiem i toruje początkującemu użytkownikowi drogę do formułowania bardziej skomplikowanych struktur składniowych (Gasek, 2014).

Produktywnym słowotwórczo jest wyraz баритон. Słownik WP rejestruje dwa przymiotniki od niego pochodne: баритональныц $\sim$ бас - bas baryton; баритонный - barytonowy. W słowniku PWN odnajdziemy natomiast jeszcze jeden przymiotnik: баритоновыц - barytonowy (instrument).

Pożytecznym z punktu widzenia użytkownika zabiegiem stosowanym w obu słownikach są przykłady użycia wyrazów (konteksty). Wykorzystując gotowe wyrażenia, użytkownik jest w mniejszym stopniu narażony na popełnienie błędu, np. podczas stosowania kolokacji. Słowniki podają m.in. następujące muzyczne połączenia wyrazowe:

Słownik PWN:

аккомпанемент - akoтрапіатепt $\checkmark$ под аккомпанемент (при звуках, в сопровождении, напр. рояля, гитары, дождя) - przy akompaniamencie; кониерт - koncert $\checkmark$ кониерт для скрипки с оркестром - koncert na skrzypсе $z$ orkiestra; концерт по заявкам радиослушателей - radiowy koncert żyсzеń; концерт по письмам радиослушателей - listowy koncert $\dot{z} y c z e n ́$ ( $w$ radiu) - wydaje się, że dwa ostatnie przykłady użycia są ze sobą tak zbieżne, iż można by poprzestać na jednym z nich, bez szkody dla korzystającego;

музыкальный - 1. тизусzпу, 2. (одарёныьый) тиzykalny, 3. (напр. голос: мелодичный) melodyjnу, м музыкальная шкатулка - pozytywka; музыкальный центр (аудиоаппаратура) - wieża (hi-fi).

Słownik WP:

нотный - nиtоwy ая бумага - papier nutowy; ые линейки - linie nutowe; гая система - system пutowy; ый стан - pięciolinia; 
опера - орега; классическая - opera klasyczna; петь в е - śpiewać w operze; $\diamond$ из другой $\sim$ bl, не из той bl - iron. zinnej beczki².

Już tych kilka przykładów wystarczy, by zauważyć odmienność strategii stosowanych w obu słownikach. Z punktu widzenia ekonomii miejsca właściwsze rozwiązanie w umieszczaniu przykładów użycia w artykułach hasłowych stosowane jest w słowniku WP. Znak z dodaną końcówką deklinacyjną nie wymusza powtarzania wyrazu wyjściowego, co obserwujemy w słowniku PWN. Taki zabieg umożliwia rozszerzenie liczby kontekstów bądź też umieszczenie ich przy większej liczbie słów, co może być zjawiskiem jak najbardziej pożądanym. Z drugiej jednak strony korzystanie z pełnych wyrażeń umożliwia użytkownikowi zapamiętywanie ich w całości. Aktywizacja pamięci wzrokowej ułatwia przyswajanie języka. Który zabieg jest słuszniejszy? Decyzja należy do użytkownika.

Nie ulega wątpliwości, że muzyka jest częścią kultury, zatem w języku muzyki również odnajdziemy pojęcia zakorzenione $\mathrm{w}$ kulturze, $\mathrm{w}$ naszym przypadku - rosyjskiej. Takie słowa wymagają szczególnej uwagi podczas procesu przekładu. O tym pisze m.in. Halina Bartwicka, zwracając uwagę na „ekstralingwistyczne aspekty przekładu” lub w innym miejscu: „słowa z komponentem kulturowym (слова с культурным компонентом)”. Informacja słownikowa jest zwykle niewystarczająca, z uwagi głównie na ograniczoność miejsca. Użytkownik słownika musi mieć świadomość, iż bardzo trudno jest sformułować wszelkie konotacje zawarte w danym słowie w krótkiej definicji, co, oczywiście, nie zwalnia autorów słownika z poszukiwań i prób jak najwierniejszego przekładu elementów kulturowych. Niezwykle ważne jest w takim przypadku uwzględnienie wiedzy uprzedniej odbiorcy, u którego dane słowo powinno wywołać taki efekt komunikacyjny jak u osoby, dla której kultura ta jest kulturą rodzimą (Bartwicka, 2006b). Uczona ta podkreśla też, że słownik dwujęzyczny powinien zawierać taką liczbę kulturowych haseł, by dać użytkownikowi pewną wiedzę na temat danego kraju. Najmniej pożądanym zaś sposobem tłumaczenia tego typu leksyki jest jej dosłowny, bezpośredni przekład (Bartwicka, 2006a). W wyekscerpowanej ze słowników leksyki również odnajdziemy słowa o podłożu kulturowym. Zbadajmy trafność odpowiedników w języku polskim na przykładzie wybranych słów:

${ }^{2}$ Ostatni przykład oczywiście wykracza poza sferę muzyczną. Wyrażenie to ma znaczenie przenośne. 
- запевала

Słownik PWN: запевала - 1. przodownik chóru, 2. (mom, кто первым начинает что-либо; инициатор) wodzirej.

Słownik WP: запевала - 1. przodownik chóru, 2. przen. wodzirej.

ЗАПЕВАЛА - 1. Певеи, исполняющий запев (1 зн.), 2. Разг. Тот, кто первым начинает что-л.; инициатор (Большой толковый словарь, b.d.).

Definicja rosyjska wyraźnie wskazuje na czynny udział takiej osoby w śpiewie. Tymczasem słownikowe objaśnienie przywodzi na myśl raczej dyrygenta, kierownika chóru, niekoniecznie zaś osobę, która jedynie rozpoczyna wspólny śpiew. Przodownik chóru wywołuje konotacje w świadomości użytkownika $\mathrm{z}$ teatrem antycznym, w którym chór miał swoje określone zadania, a jedną z postaci wypowiadających się był właśnie przodownik chóru.

- балалайка

Słownik PWN: балалайка - bałałajka.

Słownik WP: балалайка - bałałajka, bałabajka.

W obu przypadkach mamy do czynienia $\mathrm{z}$ transferem obcego słowa do języka polskiego. Zapewne $\mathrm{z}$ uwagi na popularność tegoż instrumentu i oczywiste konotacje z kulturą rosyjską słowo to nie zostało opatrzone kwalifikatorem ani dodatkową eksplikacją. Wątpliwości może jedynie budzić bałabajka. Jest to słowo zdecydowanie rzadziej używane niż bałałajka (jeśli używane w ogóle).

Szersze objaśnienia byłyby natomiast wskazane w odniesieniu do słów: свирель, сопель.

- свирель

Słownik PWN: свирель - fujarka/piszczałka.

Słownik WP: свирель - muz. fujarka, piszczałka.

Zastosowano tu generalizację, ponieważ w słowniku języka rosyjskiego przeсzytamy, że СВИРЕЛЬ - 1. Русский народный музыкальный инструмент в виде дудки из дерева или тростника, 2. Бытовое название духовых инструментов типа одноствольных и двуствольных фьлейт (Большой толковый словарь, b.d.).

Zabieg ten nie budziłby większych zastrzeżeń (nie jest to słownik terminologii muzycznej, ale słownik ogólny), gdyby nie niemal identyczna definicja kolejnego instrumentu: 
- сопель

Słownik WP (PWN nie rejestruje tego słowa): сопель - piszczałka, fujarka, fletnia. Odwołajmy się po raz kolejny do definicji rosyjskiej: СОПЕЛЬ - Народныц̆ (русский, украинский, белорусский) духовой музыкальный инструмент, род свистковой брлейты, свирели (Большой толковый словарь, b.d.).

Instrumenty są do siebie podobne, jednak największe zastrzeżenia budzi fletnia podana jako jedno ze znaczeń. Свирель i сопель mają postać pojedynczej piszczałki, natomiast fletnia to kilka połączonych ze sobą piszczałek, zatem takie tłumaczenie nie odzwierciedla specyfiki tegoż instrumentu.

- домбра

Słownik WP (PWN nie rejestruje tego słowa): домбра - muz. dombra (kazachski instrument strunowy).

Zwróćmy uwagę na różnice w realizacji artykułów hasłowych w słowniku WP. Сопель і свирель zostały niejako zrównane semantycznie, bez wskazania na to, iż są one instrumentami ludowymi. Домбра została przetranskrybowana $\mathrm{z}$ podaną $\mathrm{w}$ nawiasie wskazówką interpretacyjną. Warto by się zastanowić nad ujednoliceniem sposobu podawania informacji. Godnym zauważenia jest jednak fakt, iż te, jakkolwiek nieszczególnie powszechne słowa, znalazły się w słowniku ogólnym.

- ансамбль

Słownik PWN: ансамбль - zespót.

Słownik WP: ансамбль - zespół, песни и пляски - zespół pieśni i tańca;

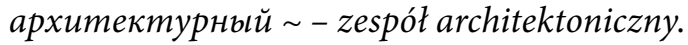

Komentarza wymaga łączliwość wyrazu ансамбль z innymi wyrazami. Tłumaczenie w słowniku PWN nie daje żadnych wskazówek co do użycia słowa, tymczasem bywa ono często używane w odniesieniu do zespołu muzycznego, co właściwiej jest tłumaczyć jako групnа. Ансамбль z reguły odnosi się do zespołów ludowych, wykonujących narodową muzykę, popularyzujących kulturę danego kraju, ale też do rodzaju partii operowej. W drugim z omawianych przypadków należałoby przetłumaczyć to słowo raczej jako ansambl.

Kultura wychodzi często poza podziały administracyjno-polityczne, w związku z czym obserwujemy ekspansję prądów, tendencji, a co za tym idzie - leksyki nazywającej takie zjawiska. Spora część leksyki muzycznej została zapożyczona $\mathrm{z}$ innych języków. Wbrew powszechnemu przekonaniu 
nie są to jedynie wpływy włoskie, ale też niemieckie, greckie i inne, choć prawdą jest, że zapożyczenia z języka włoskiego pozostają najbardziej znane (Dąbkowski, 1997). Nie są to jednak egzotyzmy. Mają one swoje denotaty w języku rosyjskim, zdążyły się już więc zadomowić w rosyjskiej kulturze muzycznej, muzycznej, osoby zajmujące się muzyką rozumieją je i ich używają. Przykładami niech będą: ариозо, каприччо, кантабиле, пициикато, престо. Słowa te zasymilowały się na tyle, iż zapisywane są cyrylicą. Walery P. Berkow podkreśla konieczność włączania słów obcojęzycznych do słowników języka-biorcy, biorąc pod uwagę częstotliwość ich użycia (Берков, 1973).

Odchodząc od kontekstu kulturowego, należałoby jeszcze zwrócić uwagę na całkowicie błędne przetłumaczenie słowa темперация, które przełożono jako strój równomiernie temperowany (Słownik WP, PWN natomiast nie rejestruje tego słowa). Słowo темперация należałoby przetłumaczyć po prostu jako temperacja (bo taki właśnie termin funkcjonuje w teorii muzyki), czyli proces zmierzający do wyrównania odległości interwałowych na instrumencie klawiszowym tak, by uzyskać możliwie najczystsze brzmienie interwałów i akordów.

Nieścisłość obserwujemy także w przypadku słowa тональность, w obu słownikach tłumaczonego jako tonacja, w słowniku WP opatrzonego kwalifikatorem muz. szt. Spójrzmy na definicję: тональность - высота, на которой расположен лад (Вахромеев, 1961, s. 107). Jest to zatem pojęcie bliskie tonacji w polskiej teorii muzyki. Można zaryzykować stwierdzenie, że warianty tłumaczeniowe tych słów nie są w pełni tożsame semantycznie. Wynika to $\mathrm{z}$ odmiennej historii teorii muzyki w Polsce i Rosji oraz różnego rozumienia tych pojęć. Тональность, лад, гамма oraz tonacja, tonalność, gama, skala - to pojęcia, których znaczenia krzyżują się częściowo, nie jest możliwe wyznaczenie dokładnego ekwiwalentu, w całości pokrywającego się semantycznie. Przyznać jednak należy, że słowo тональность jest w praktyce tłumaczone jako tonacja np. w tytułach utworów.

$\mathrm{Na}$ szczególną uwagę zasługuje słowo yнmертон ${ }^{3}$ tłumaczone w słowniku WP jako muz. nuta wtórna. W podręczniku do zasad muzyki (Zasady muzyki F. Wesołowski) nie odnajdziemy takiego terminu muzycznego jak nuta wtórna. W БТС (Большой толковый словарь, b.d.) podana jest następująca definicja: УНТЕРТО'Н - тон, входящий в состав сложного звука, более низкий, чем

\footnotetext{
${ }^{3}$ Niem. „Unterton”, ang. „undertone” lub „subharmonic”.
} 
основной; добавочный низкий тон. Sprawa jest jednak bardziej skomplikowana. Chodzi tu о римановскую гипотезу унтертонов - teorię stworzoną pod koniec XIX w. przez Hugo Riemanna (pracowali nad nią też inni badacze), opierającą się na lustrzanym odbiciu tonów dźwiękowych i odwrotnej kolejności alikwotów. W rosyjskiej teorii muzyki yнтертон przeciwstawia się pojęciu обертон (Рыжкова, 2012). Teoria ta budzi jednak sporo zastrzeżeń $\mathrm{z}$ uwagi na zbyt słabą podstawę fizyczną i akustyczną. Alikwoty te, zgodnie z prawami akustyki, nie są słyszalne. Częściej wspomina się o psychofizycznych przesłankach tego „zjawiska” (Райc, 2012).

Zarysowana w niniejszym artykule problematyka przekładu leksyki muzycznej na przykładzie wybranych dwóch słowników dwujęzycznych pozwala zatem zrozumieć, przed jakim problemem staje leksykograf tworzący lub współtworzący dwujęzyczny słownik ogólny. Oprócz leksyki ogólnej musi on wybrać i zawrzeć w nim pewną część leksyki sprofilowanej, mając jednak stale na uwadze, iż praca ta nie powinna zmierzać w kierunku przekształcania słownika w leksykon dziedzinowy, tematyczny. Nie należy jednak oczywiście eliminowaćleksyki specjalistycznej ze słownika ogólnego, gdyż z takimi słowami również spotykamy się na co dzień. Istnieje więc realna potrzeba przybliżania jej użytkownikowi. Analiza wybranej grupy tematycznej w ujęciu leksykograficznym potwierdza ogólną tendencję oceniającą słowniki PWN i WP. Terminologia również wymaga aktualizacji, tymczasem w słownikach, zwłaszcza w słowniku WP, obserwujemy obecność zdezaktualizowanej leksyki, która nie jest przydatna użytkownikowi. Nie znajduje też uzasadnienia umieszczanie w słowniku ogólnym pewnej grupy słów, z którymi w swojej pracy nie spotykają się nawet praktykujący muzycy, co potwierdzono w konsultacjach. W wielu przypadkach największym problemem okazała się jednak nieprzystawalność leksyki pod względem semantycznym, dlatego też niektóre z przytoczonych haseł warto rozważyć pod kątem doprecyzowania bądź korekty odpowiedników w języku polskim.

\section{Bibliografia}

Bartwicka, H. (2006a). К проблеме культурно-коннотированной лексики в двуязычных словарях (на материале русско-польских словарей). W H. Bartwicka, Ze studiów konfrontatywno-przekładowych nad językiem polskim i rosyjskim (ss. 26-35). Warszawa: Wydawnictwo TAKT.

Bartwicka, Н. (2006b). Несколько слов о внеязыковых аспектах перевода. W H. Bartwicka, Ze studiów konfrontatywno-przekładowych nad językiem polskim i rosyjskim (ss. 35-41). Warszawa: Wydawnictwo TAKT. 
Borowska, A. P. (2004). Zasady konstruowania trójjęzycznego słownika dydaktycznego z zakresu terminologii muzycznej. W J. Lewandowski (Red.), Języki specjalistyczne 4: Leksykografia terminologiczna - teoria i praktyka (ss. 221-230). Warszawa: Katedra Języków Specjalistycznych Uniwersytetu Warszawskiego.

Dąbkowski, G. (1997). Europejska terminologia muzyczna. Kielce: Wydawnictwo Wyższej Szkoły Pedagogicznej im. Jana Kochanowskiego.

Gasek, B. (2014). Wielkie słowniki rosyjsko-polskie a dydaktyka przekładu. Lingwistyka Stosowana, 11, 43-51. Pobrano z http://www.ls.uw.edu.pl/documents/7276721/12447778 /Lingwistyka+Stosowana+11+Bogumil+Gasek.pdf

Kozdra, M. (2017). Dobór haseł w słownikach ogólnych rosyjsko-polskich i polsko-rosyjskich. W J. Wawrzyńczyk \& P. Wierzchoń (Red.), Wokót „300 tysięcy polskich słów”: Wstęp do hasłownikologii (ss. 205-222). Warszawa: BEL Studio. Pobrano z https://depot.ceon.pl /bitstream/handle/123456789/11862/Dobór haseł w słownikach ogólnych_Michał Kozdra .pdf? sequence $=1 \&$ is Allowed $=y$

Mela, M. (2008). O problemach terminologii muzycznej w kontekście konstruowania branżowego słownika terminologicznego. W K. Fordoński \& M. Łukasik (Red.), Piękno języka specjalistycznego a precyzja języka literackiego (ss. 45-53). Warszawa: Katedra Języków Specjalistycznych Uniwersytetu Warszawskiego.

Sobol, E. (2004). Wstęp. W J. Wawrzyńczyk (Red.), Wielki słownik rosyjsko-polski z kluczem polsko-rosyjskim (s. 5). Warszawa: PWN.

Берков, В. П. (1973). Вопросы двуязычной лексикографии: Словник. Ленинград: Изд-во ЛГУ.

Вахромеев, В. А. (1961). Элементарная теория музыки. Москва: Государственное музыкальное издательство. Pobrano z http://музшкола13.екатеринбург.pф/documents /[classon.ru]_Vaxromeev-Elementarnaya_teoriya_muziki.pdf

Райс, М. (2012). Чувства и расчёт в функциональной теории Хуго Римана. Израиль XXI, 2012(31). Pobrano z https://web.archive.org/web/20160915122421/http://www.21israel -music.com/Riemann.htm

Рыжкова, Н. А. (2012). Развитие функциональной теории в отечественной музыкальной науке XX века. Искусство музыки: Теория и история, 2012(6), 125-156. Pobrano z http://sias.ru/upload/iblock/6fa/rijkova.pdf

\section{Słowniki}

Mirowicz, A., i in. (1993). Wielki słownik rosyjsko-polski (T. 1-2). Warszawa: Wiedza Powszechna.

Wawrzyńczyk, J. (Red.). (2004). Wielki słownik rosyjsko-polski z kluczem polsko-rosyjskim. Warszawa: PWN.

Большой толковый словарь. (b.d.). Pobrano z http://www.gramota.ru/slovari/info/bts/ 


\section{Bibliography (Transliteration)}

Bartwicka, H. (2006a). K probleme kul'turno-konnotirovannoŭ leksiki v dvuiazychnykh slovariakh (na materiale russko-pol'skikh slovareǐ). In H. Bartwicka, Ze studiów konfrontatywno-przekładowych nad językiem polskim i rosyjskim (pp. 26-35). Warszawa: Wydawnictwo TAKT.

Bartwicka, H. (2006b). Neskol'ko slov o vneiazykovykh aspektakh perevoda. In H. Bartwicka, Ze studiów konfrontatywno-przekładowych nad językiem polskim i rosyjskim (pp. 35-41). Warszawa: Wydawnictwo TAKT.

Berkov, V. P. (1973). Voprosy dvuiazychnoĭ leksikografii: Slovnik. Lenigrad: Izd-vo LGU.

Borowska, A. P. (2004). Zasady konstruowania trójjęzycznego słownika dydaktycznego z zakresu terminologii muzycznej. In J. Lewandowski (Ed.), Języki specjalistyczne 4: Leksykografia terminologiczna - teoria i praktyka (pp. 221-230). Warszawa: Katedra Języków Specjalistycznych Uniwersytetu Warszawskiego.

Dąbkowski, G. (1997). Europejska terminologia muzyczna. Kielce: Wydawnictwo Wyższej Szkoły Pedagogicznej im. Jana Kochanowskiego.

Gasek, B. (2014). Wielkie słowniki rosyjsko-polskie a dydaktyka przekładu. Lingwistyka Stosowana, 11, 43-51. Retrieved from http://www.ls.uw.edu.pl/documents/7276721/12447778 /Lingwistyka+Stosowana+11+Bogumil+Gasek.pdf

Kozdra, M. (2017). Dobór haseł w słownikach ogólnych rosyjsko-polskich i polsko-rosyjskich. In J. Wawrzyńczyk \& P. Wierzchoń (Eds.), Wokót "300 tysięcy polskich słów”: Wstęp do hasłownikologii (pp. 205-222). Warszawa: BEL Studio. Retrieved from https://depot.ceon.pl /bitstream/handle/123456789/11862/Dobór haseł w słownikach ogólnych_Michał Kozdra .pdf?sequence $=1 \&$ is Allowed $=y$

Mela, M. (2008). O problemach terminologii muzycznej w kontekście konstruowania branżowego słownika terminologicznego. In K. Fordoński \& M. Łukasik (Eds.), Piękno języka specjalistycznego a precyzja języka literackiego (pp.45-53). Warszawa: Katedra Języków Specjalistycznych Uniwersytetu Warszawskiego.

Raĭs, M. (2012). Chuvstva i raschët v funktsional'noĭ teorii Khugo Rimana. Izrail' XXI, 2012(31). Retrieved from https://web.archive.org/web/20160915122421/http://www.21israel-music .com/Riemann.htm

Ryzhkova, N. A. (2012). Razvitie funktsional'noĭ teorii v otechestvennoŭ muzykal'noŭ nauke XX veka. Iskusstvo muzyki: Teoriia $i$ istoriia, 2012(6), 125-156. Retrieved from http://sias .ru/upload/iblock/6fa/rijkova.pdf

Sobol, E. (2004). Wstęp. In J. Wawrzyńczyk (Ed.), Wielki słownik rosyjsko-polski z kluczem polsko-rosyjskim (p. 5). Warszawa: PWN.

Vakhromeev, V. A. (1961). Élementarnaia teoriia muzyki. Moskva: Gosudarstvennoe muzykal'noe izdatel'stvo. Retrieved from http://музшкола13.екатеринбург.рф/documents /[classon.ru]_Vaxromeev-Elementarnaya_teoriya_muziki.pdf 
Dictionaries

Bol'shoŭ tolkovyı̆ slovar'. (n.d.). Retrieved from http://www.gramota.ru/slovari/info/bts/

Mirowicz, A., et al. (1993). Wielki słownik rosyjsko-polski (Vols. 1-2). Warszawa: Wiedza Powszechna.

Wawrzyńczyk, J. (Ed.). (2004). Wielki słownik rosyjsko-polski z kluczem polsko-rosyjskim. Warszawa: PWN.

\section{Musical Lexis in Russian-Polish Lexicography: Present State and Users' Needs}

\section{Summary}

In order to meet the expectations of receivers, who come across vocabulary from various areas in their everyday life, general bilingual dictionaries include lexis from many different fields. This article analyses one such group in Russian-Polish lexicography: musical lexis. The analysis offered here considers translation pairs extracted from two most comprehensive Russian-Polish dictionaries. The study categorises musical lexis into semantic classes and verifies the accuracy, semantic relevance and currency of provided equivalents. The aim was to establish whether general bilingual lexicography meets the needs of users looking for equivalents in this lexical area. Basing on selected material, the article also compares the structure of entries in each dictionary and considers cultural background of musical lexis in the context of Russian culture. To illustrate the issues in focus, the study comments on a number of examples and proposes some solutions to problematic cases. 


\section{Leksyka muzyczna w rosyjsko-polskiej leksykografii. Stan obecny versus potrzeby użytkowników}

\section{Streszczenie}

Dwujęzyczne słowniki ogólne obejmują leksykę z wielu dziedzin, wychodząc naprzeciw oczekiwaniom odbiorców, którzy w życiu codziennym stykają się ze zróżnicowanym tematycznie słownictwem. Jedną z takich dziedzin jest muzyka. Związana z nią leksyka zarejestrowana w rosyjsko-polskiej leksykografii jest obiektem naszych badań. Analiza opiera się na parach przekładowych wyekscerpowanych $\mathrm{z}$ dwóch najobszerniejszych słowników rosyjsko-polskich. W pracy dokonano podziału leksyki muzycznej na klasy semantyczne. Poddano weryfikacji trafność ekwiwalentów przekładowych, ich zgodność semantyczną oraz stopień aktualności terminów, zawarty w słownikach. Działania te miały na celu sprawdzenie, na ile dwujęzyczna leksykografia ogólna odpowiada potrzebom użytkowników w zakresie dostępności odpowiedników dla tego typu leksyki. Bazując na wybranym materiale, dokonano porównania budowy artykułu hasłowego w obu słownikach. Zwrócono uwagę na podłoże kulturowe leksyki muzycznej w kontekście kultury rosyjskiej. Ilustracją dla omawianych treści są liczne przykłady wraz z komentarzami oraz, niekiedy, propozycje rozwiązań kwestii problemowych.

Keywords: music; lexicography; translation; Russian culture

Słowa kluczowe: muzyka; leksykografia; tłumaczenie; kultura rosyjska

Ewelina Parafińska-Korybska, The John Paul II Catholic University of Lublin, Lublin

ORCID: https://orcid.org/0000-0003-0508-0321

Correspondence: ewelina.parafinska@wp.pl

The preparation of this article was financed by the author.

Competing interests: The author declares that she has no competing interests. 